\title{
Pengaruh micro teaching dan kegiatan ekstrakurikuler terhadap pembentukan karakter tanggung jawab mahasiswa
}

\author{
Muhammad Arif Al-Fikri a, 1*, Marzuki ${ }^{\text {b, } 2}$ \\ a Program Studi Pendidikan Pancasila dan Kewarganegaraan, Program Pascasarjana, Universitas \\ Negeri Yogyakarta, Yogyakarta, Indonesia \\ ${ }^{b}$ Jurusan Pendidikan Kewarganegaraan dan Hukum, Fakultas Ilmu Sosial, Universitas Negeri \\ Yogyakarta, Yogyakarta, Indonesia \\ ${ }^{1}$ al.fikri029@gmail.com*; ${ }^{2}$ marzuki@uny.ac.id \\ *korespondensi penulis
}

\begin{tabular}{ll}
\hline Informasi artikel & ABSTRAK \\
\hline Kata kunci: & Penelitian ini bertujuan untuk mengetahui pengaruh micro teaching dan kegiatan \\
micro teaching, & ekstrakurikuler terhadap pembentukan karakter tanggung jawab mahasiswa Program \\
ekstrakurikuler, & Studi Pendidikan Kewarganegaraan Universitas Negeri Yogyakarta. Jenis penelitian \\
tanggung jawab & ini ex-post facto dengan pendekatan kuantitatif. Sampel penelitian yaitu 54 mahasiswa \\
& yang sudah menempuh mata kuliah micro teaching sekaligus juga mengikuti kegiatan \\
& ekstrakurikuler mahasiswa. Hasil penelitian menunjukkan terdapat pengaruh positif \\
& dan signifikan terhadap pembentukan karakter tanggung jawab mahasiswa. \\
& Sumbangan efektif micro teaching sebesar 34,6\%. Terdapat pengaruh positif dan \\
& signifikan kegiatan ekstrakurikuler mahasiswa terhadap pembentukan karakter \\
& tanggung jawab mahasiswa. Sumbangan efektif kegiatan ekstrakurikuler sebesar \\
& 10,4\%. Terdapat pengaruh positif dan signifikan micro teaching dan kegiatan \\
& ekstrakurikuler mahasiswa secara bersama-sama terhadap pembentukan karakter \\
& tanggung jawab, ditunjukkan dengan nilai F hitung (20,823) lebih besar dari F tabel \\
& (3,18) dan nilai signifikansi sebesar 0,000 lebih kecil dari 0,05, dengan sumbangan \\
& efektif sebesar 45,0\%.
\end{tabular}

Keywords:

Micro teaching Extracurricular Responsibility

\begin{abstract}
This research aims to know the effect of micro teaching end extracurricular on the establishment of character responsibility of Pancasila and Civics Education Program students. students. This research was ex-post facto with quantitative approach. The sample of this research were 54 students who have already attended courses of micro teaching as well as followed extracurricular activities of students. The research results indicate that there is a positive and significant effect of micro teaching on the establishment of the character responsibility. Micro teaching variable gives effective contribution amounting to $34.6 \%$. There is a positive and significant effect of extracurricular activities of the students on the establishment of the character responsibility of students. Extracurricular activities variable of the students gives effective contribution amounting to $34.6 \%$. There is a positive and significant effect of micro teaching and extracurricular activities of the students on the establishment of the character responsibility of student. This can be seen from the $F$ observed (20.823) which is more than F table (3.18) from the value of significance 0.000 smaller than 0.05. The coefficient of determination is $45.0 \%$.
\end{abstract}

Copyright (C) 2018 Muhammad Arif Al-Fikri dan Marzuki. All Right Reserved

\section{PENDAHULUAN}

Berdasar amanat Undang-Undang Nomor 20 Tahun 2003 tentang Sistem Pendidikan Nasional sangat jelas bahwa mendidik pada hakikatnya adalah mempunyai fungsi dan tujuan untuk mengembangkan potensi diri peserta didik agar peserta didik memiliki kemampuan yang dilandasi oleh keimanan dan ketakwaan, kepribadian, akhlak mulia, dan kemandirian. Lebih jelasnya lagi pendidikan 
mempunyai fungsi dan berusaha untuk membentuk karakter positif pada para peserta didik. Akan tetapi pada kenyataannya di kalangan siswa dan mahasiswa kemerosotan moral dan karakter begitu memprihatinkan. Kemerosotan karakter tersebut sebenarnya sudah teridentifikasi Lickona sejak lama. Generasi muda menunjukkan kecenderungan pada kemunduran karakter seperti maraknya tawuran dan penyalahgunaan obat terlarang (Lickona, 2009).

Membahas karakter tidak bisa lepas dari karakter tanggung jawab. Karakter tanggung jawab merupakan salah satu kekuatan untuk mengembangkan potensi penuh kemanusiaan untuk menjadi orang terbaik dan menjadi dasar landasan sekolah yang tidak hanya memperbolehkan, tetapi mengharuskan para guru untuk memberikan pendidikan mengenai tanggung jawab tersebut sebagai nilai moral mendasar (Cogan \& Derricott, 1998; Nuci, Narvaez, \& Krettenauer, 2014; Spears, 2010). Penanaman moral dan karakter pada remaja salah satunya dapat dilakukan melalui dunia pendidikan. Universitas atau Perguruan Tinggi sebagai lembaga pendidikan merupakan salah satu institusi penting dalam membentuk karakter, tidak terkecuali Universitas Negeri Yogyakarta (UNY) sebagai Lembaga Pendidikan Tenaga Kependidikan (LPTK). Terlebih lagi untuk Program Studi Pendidikan Pancasila dan
Kewarganegaraan (PPKn) yang merupakan pencetak calon guru PPKn yang selama ini sangat dekat hubungannya dengan karakter. Penjelasan tentang penyiapan calon tenaga pendidik profesional yang berkarakter selaras dengan visi dan misi dari Program Studi PPKn. Salah satu misinya adalah mampu menjadi salah satu institusi pembangunan watak bangsa (nation and character building) demi terwujudnya warga masyarakat (civil soviety) yang demokratis dan bertanggungjawab. Mahasiswa Prodi PPKn merupakan subjek didik di pendidikan tinggi dan juga calon guru PPKn yang selama ini identik dengan pembentukan dan pendidikan karakter dalam dunia pendidikan. Jadi untuk para calon guru PPKn dan juga guru PPKn harus mencerminkan karakter yang positif pada dirinya untuk membangun karakter calon penerus bangsa.

Jenis dari kegiatan akademik yang wajib diambil dan ditempuh oleh mahasiswa calon guru adalah micro teaching. Tujuan yang ingin dicapai dengan micro teaching supaya guru/calon guru supaya memiliki kompetensi pengetahuan nilai, sikap, dan tingkah laku yang diperlukan dalam profesinya (Asmani, 2010). Laboratorium pengajaran atau pengajaran mikro terdapat hubungan dengan sikap, kepribadian, dan perilaku calon guru (Austad, 1972; Narvaez \& Lapsley, 2008; Reed, 1970). Pengajaran 
mikro juga mampu meningkatkan sikap positif bagi para calon guru.

Berdasarkan beberapa kajian teori dan hasil penelitian, maka sangat jelas bahwa kegiatan micro teaching tidak hanya membekali pengetahuan saja akan tetapi membekali guru dan atau calon guru dengan nilai, sikap dan tingkah laku yang diperlukan dalam menjalankan profesinya. Tidak sebatas pada ukuran kognitif mahasiswa calon guru tetapi juga sampai pada ranah moral atau karakter mahasiswa calon guru.

Kegiatan ekstrakurikuler dilakukan untuk memenuhi tuntutan penguasaan kompetensi pelajaran, pembentukan karakter bangsa, dan peningkatan kecakapan hidup (Hamalik, 2007). Kegiatan ekstrakurikuler mempunyai pengaruh terhadap pembentukan pribadi yang lebih baik, menjadi dasar untuk perubahan ke arah yang positif, dan juga membentuk tingkah laku yang baik selama masa remaja (Bundick, 2011; Eccles, Barber, Stone, \& Hunt, 2004; Feldman \& Matjasko, 2005; Keser, Akar, \& Yildrim, 2011). Perubahan ke arah positif tersebut antara lain kepekaan terhadap aturan-aturan sosial, pengembangan rasa empati dan membangun kesadaran akan perbedaan dan menghargai perbedaan. Dengan membentuk tingkah laku yang baik pada remaja, maka kegiatan ekstrakurikuler juga mampu mengurangi masalah perilaku pada remaja. Berdasar uraian di atas terlihat bahwa micro teaching dan kegiatan ekstrakurikuler memiliki pengaruh terhadap karakter tanggung jawab, namun belum ada kajian lebih lanjut yang mengungkapkan seberapa besar pengaruhnya

\section{METODE}

Jenis penelitian ini adalah ex-post facto karena data yang diperoleh adalah data hasil dari peristiwa yang sudah berlangsung sehingga peneliti hanya mengungkap fakta berdasarkan pengukuran gejala yang telah ada pada responden. Penelitian ini bertujuan untuk mengetahui pengaruh micro teaching dan kegiatan ekstrakurikuler mahasiswa terhadap pembentukan karakter tanggung jawab mahasiswa.

Penelitian ini telah dilaksanakan di Program Studi Pendidikan Pancasila Kewarganegaraan (PPKn) dan juga di Student Center (SC) Universitas Negeri Yogyakarta (UNY). Populasi dalam penelitian ini adalah mahasiswa Prodi PPKn yang sudah menempuh mata kuliah micro teaching sekaligus mahasiswa yang mengikuti kegiatan ekstrakurikuler. Dalam pengambilan sampel penelitian menggunakan teknik sampling jenuh. Setelah melakukan penelitian jumlah mahasiswa PKn yang sudah mengambil atau menempuh mata kuliah micro teaching sekaligus mahasiswa yang mengikuti kegiatan ekstrakurikuler mahasiswa terdapat sebanyak 54 mahasiswa. 
Teknik yang digunakan untuk mengumpulkan data pada penelitian ini adalah menggunakan teknik kuesioner berupa angket. Angket yang digunakan dalam penelitian ini menggunakan kuesioner dengan Skala Likert dengan empat alternatif pilihan. Kuesioner ini digunakan untuk mengukur variabel micro teaching, kegiatan ekstrakurikuler, dan karakter tanggung jawab mahasiswa.

\section{HASIL DAN PEMBAHASAN}

Berdasar analisis deskriptif dapat terlihat kecenderungan dan distribusi data tiap-tiap variabel pada penelitian sebagai berikut. Pertama, distribusi kecenderungan variabel micro teaching dapat dilihat pada gambar di bawah ini

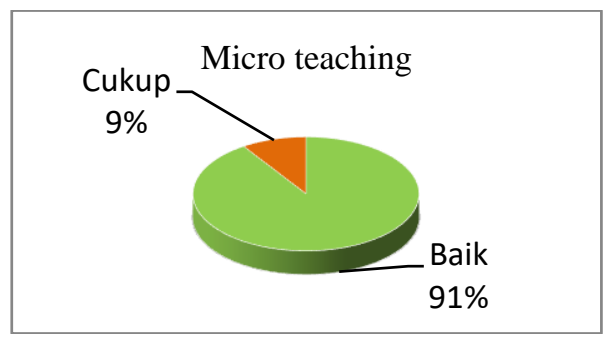

Gambar 1. Diagram Pie Kecenderungan Variabel Micro Teaching Berdasarkan Penilaian Mahasiswa

Gambar di atas menunjukkan kecenderungan variabel micro teaching pada kategori baik sebanyak 49 mahasiswa sebesar 90,7\%, kemudian pada kategori cukup sebanyak 5 mahasiswa sebesar 9,3\%, dan pada kategori kurang tidak ada. Dengan demikian, dapat dikatakan bahwa kecenderungan variabel micro teaching pada kategori baik.
Kedua, distribusi kecenderungan variabel Ekstrakurikuler dapat dilihat pada gambar 2.

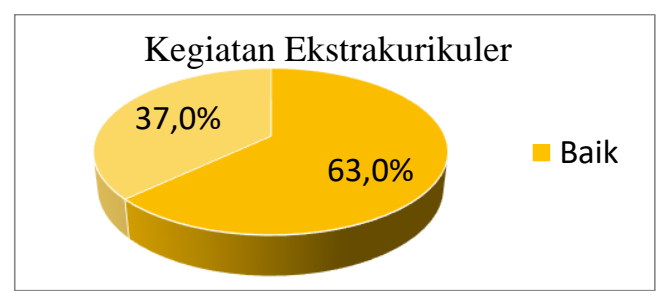

Gambar 2. Diagram Pie Kecenderungan Variabel Kegiatan Ekstrakurikuler Berdasarkan Penilaian Mahasiswa

Diagram diatas menunjukkan kecenderungan variabel kegiatan ekstrakurikuler pada kategori baik sebesar 63,0\%, kemudian pada kategori cukup sebesar 37,0\%, dan pada kategori kurang tidak ada. Dengan demikian dapat dikatakan bahwa kecenderungan variabel kegiatan ekstrakurikuler berdasarkan penilaian mahasiswa dalam kategori baik.

Ketiga, distribusi kecenderungan variabel Karakter Tanggung Jawab dapat dilihat pada gambar 3 .



Gambar 3. Diagram Pie Kecenderungan Variabel Pembentukan Karakter Tanggung Jawab

Diagram di atas menunjukkan kecenderungan variabel pembentukan karakter tanggung jawab pada kategori cukup sebesar 88,9\%, dan pada kategori kurang sebesar $11,1 \%$. Dengan demikian dapat dikatakan bahwa kecenderungan 
variabel pembentukan karakter tanggung jawab pada kategori cukup.

Setelah melalui analisis deskriptif dana juga dilakukan uji persyaratan kemudian dianalisis dengan menggunakan regresi sederhana dan juga regresi ganda untuk Tabel 3. Hasil Regresi Sederhana Variabel Micro

Teaching terhadap Pembentukan Karakter Tanggung Jawab Mahasiswa

\begin{tabular}{|c|c|c|c|c|}
\hline Var & $\begin{array}{r}\text { Unsta } \\
\text { Co } \\
\end{array}$ & & $\begin{array}{c}\mathrm{t} \\
\text { hitung }\end{array}$ & Sig. \\
\hline $\begin{array}{c}\text { Konstan } \\
\text { X1 }\end{array}$ & $\begin{array}{c}11,354 \\
0,649\end{array}$ & $\begin{array}{l}5,198 \\
0,113\end{array}$ & & 5,762 \\
\hline
\end{tabular}

Berdasarkan hasil analisis di atas diperoleh nilai signifikansinya $0,000(<0,05)$ dan t hitung sebesar 5,762. Jika dibandingkan dengan nilai tabel dengan df 53 maka diperoleh 2,000 pada taraf signifikansi 5\%, maka nilai thitung $>$ tabel. Hal ini berarti bahwa terdapat pengaruh positif dan signifikan micro teaching terhadap pembentukan karakter tanggung jawab mahasiswa Prodi PPKn Universitas Negeri Yogyakarta

Tabel 4. Hasil Regresi Sederhana Variabel

Kegiatan Ekstrakurikuler terhadap

Pembentukan Karakter Tanggung Jawab Mahasiswa

\begin{tabular}{ccccc}
\hline Var & \multicolumn{2}{c}{$\begin{array}{c}\text { Unstandardize } \\
\text { d Coefficient }\end{array}$} & $\begin{array}{c}\text { Tthitun } \\
\mathbf{g}\end{array}$ & Sig. \\
\hline Konsta & 19,65 & 6,707 & 3,221 & 0,00 \\
$\mathrm{n}$ & 3 & & & 2 \\
$\mathrm{X} 2$ & 0,467 & 0,145 & & \\
\hline
\end{tabular}

Berdasarkan hasil analisis di atas diperoleh nilai signifikansinya $0,002(<0,05)$ dan $\mathrm{t}$ hitung sebesar 3,221. Jika dibandingkan dengan nilai tabel dengan df 53 maka diperoleh 2,000 pada taraf signifikansi 5\%, maka nilai thitung $>t_{\text {tabel. }}$ Hal ini berarti bahwa terdapat pengaruh positif dan signifikan mengukur besarnya hubungan variabel bebas terhadap variabel tergantung dan memprediksi variabel tergantung dengan menggunakan variabel bebas. Hasil analisis regresi sederhana dapat dilihat pada tabel 3 dan tabel 4.

kegiatan ekstrakurikuler terhadap pembentukan karakter tanggung jawab mahasiswa Prodi PPKn Universitas Negeri Yogyakarta (UNY).

Setelah analisis regresi sederhana, selanjutnya dilakukan analisis regresi berganda. Berikut hasil perhitungan regresi berganda.

Tabel 5. Hasil Analisis Regresi Berganda

\begin{tabular}{cccc}
\hline Model & $\begin{array}{c}\text { Koef. } \\
\text { Reg }\end{array}$ & t & Sig. \\
\hline Konstan & 1,284 & 0,195 & 0,846 \\
Micro Teaching & 0,576 & 5,122 & 0,000 \\
Kegiatan & 0,291 & 2,354 & 0,022 \\
Ekstrakurikuler & & & \\
\hline $\mathrm{R}=0,670$ & & & \\
$\mathrm{R}^{2}=0,450$ & & & 0,000 \\
F hitung $=$ & & & \\
20,823 & & &
\end{tabular}

Tabel 5 menunjukkan bahwa nilai $\mathrm{F}$ hitung sebesar 20,823 lebih besar dari F tabel dengan df 2: $51(20,823>3,18)$ dan nilai signifikansi sebesar 0,000 yang berarti kurang dari $0,05(0,000<0,05)$. Hal ini berarti bahwa terdapat pengaruh positif dan signifikan secara bersama-sama micro teaching dan kegiatan ekstrakurikuler mahasiswa terhadap pembentukan karakter tanggung jawab mahasiswa Prodi PKn Universitas Negeri Yogyakarta (UNY)".

Hasil analisis baik analisis menggunakan regresi sederhana maupun menggunakan analisis regresi berganda menunjukkan bahwa 
micro teaching dan kegiatan ekstrakurikuler mahasiswa secara parsial dan secara bersamasama berpengaruh signifikan terhadap pembentukan karakter tanggung jawab mahasiswa Prodi PKn Universitas Negeri Yogyakarta. Memang seharusnya antara kegiatan akademik khususnya micro teaching dan juga kegiatan ekstrakurikuler berjalan beriringan dan saling melengkapi untuk membentuk mahasiswa yang lebih baik. Bagi siswa/mahasiswa, sekolah adalah pekerjaan, dan yang perlu dilakukan di sekolah adalah melakukan yang terbaik dari kemampuan yang dimiliki. Siswa/mahasiswa memiliki tanggung jawab untuk menghadiri kelas, menghormati dan memperhatikan guru, dan menyelesaikan tugas kelas yang menggunakan upaya terbaik untuk melakukan semua itu. Setelah sekolah, siswa/mahasiswa mungkin berpartisipasi dalam ekstrakurikuler, dan harus memberikan upaya penuh pada ekstrakurikuler yang telah diikuti. Hal yang senada juga disampaikan oleh Thamrin (2012, hal. 26) yang menyatakan bahwa model pengembangan pendidikan karakter berbasis kelas yaitu terintegrasi pada setiap perkuliahan yang dilakukan oleh dosen dan berbasis komunitas (ekstrakurikuler) yang dikembangkan lewat aktivitas unit kegiatan mahasiswa (UKM). Dari proses pembudayaan dan pemberdayaan pendidikan karakter dalam konteks mikro tersebut terlihat bahwa kegiatan akademik (KBM di kelas) dan kegiatan ekstrakurikuler termasuk dalam proses untuk penanaman karakter siswa dan mahasiswa. Ditambahkan Winarni (2013, hal. 95)) yang menyatakan bahwa pelaksanaan pendidikan karakter baik melalui proses pembelajaran, kegiatan pembinaan kemahasiswaan, maupun manajemen UNY perlu dimonitor dan dievaluasi setidaktidaknya setahun sekali.

Hasil analisis menunjukkan bahwa micro teaching berpengaruh signifikan dan positif terhadap pembentukan karakter tanggung jawab mahasiswa Prodi PKn Universitas Negeri Yogyakarta. Micro teaching memang sudah seharusnya memilki hubungan dengan karakter tanggung jawab mahasiswa. Hal itu karena, micro teaching tidak hanya membekali mahasiswa dengan seperangkat pengetahuan akan tetapi juga membekali nilai, sikap, tingkah laku, dan kepribadian yang dibutuhkan dalam menjalankan profesinya sebagai pengajar dan pendidik. Penjelasan tersebut sesuai dengan teori dari Asmani (2010, hal. 38), bahwa sasaran yang hendak dicapai dengan micro teaching adalah guru/calon guru supaya memiliki seperangkat pengetahuan, keterampilan, nilai, sikap, serta tingkah laku yang diperlukan dalam profesinya.

Hasil analisis juga memperkuat dari hasil penelitian Austad (1972) mengenai hubungan antara variabel kepribadian dan kinerja mengajar tidak ada yang terbentuk secara kebetulan, akan tetapi karakteristik dan pola perilaku kepribadian mengajar dapat dibentuk melalui studi kinerja di laboratorium pengajaran atau melalui pembelajaran mikro. 
Keterampilan mengajar dan peningkatan sikap positif yang lebih besar pada siswa yang ikut secara aktif pada laboratorium pengajaran/micro teaching, akan tetapi kurang menguntungkan pada siswa yang tidak berpartisipasi secara aktif laboratorium pengajaran/micro teaching (Reed, 1970). Pengajaran mikro merekayasa tindakan mengajar yang kompleks menjadi lebih sederhana, lebih mudah untuk mengajarkan ketrampilan, dan lebih banyak hal positif yang diperoleh untuk pendidikan guru. Melalui pengajaran mikro tidak hanya pengetahuan saja yang bertambah akan tetapi juga pengalaman dan perilaku siswa.

Berdasar hasil dari analisis dan dari uraian di atas, membuktikan bahwa micro teaching bertujuan untuk mengembangkan ketrampilan dan membekali kompetensi yang diperlukan oleh calon guru. Kompetensi tersebut meliputi pengetahuan, ketrampilan, dan nilai-nilai dasar atau sikap yang harus dimiliki oleh calon guru. Maka dari itu micro teaching juga bertujuan untuk membentuk perilaku atau karakter calon guru agar lebih baik dalam pengajaran sebenarnya. Tidak sebatas pada ukuran kognitif mahasiswa calon guru tetapi juga sampai pada ranah moral atau karakter mahasiswa calon guru.

Hasil analisis juga menunjukkan bahwa kegiatan ekstrakurikuler yang diikuti mahasiswa berpengaruh signifikan dan positif terhadap pembentukan karakter tanggung jawab mahasiswa Prodi PKn Universitas Negeri Yogyakarta. Hasil analisis tersebut menguatkan teori pendapat Hamalik (2010, hal. 242), bahwa kegiatan ekstrakurikuler dilakukan untuk memenuhi tuntutan penguasaan kompetensi pelajaran, pembentukan karakter bangsa, dan peningkatan kecakapan hidup. Kegiatan ekstrakurikuler bersama dengan pendidikan formal lebih mungkin untuk mengembangkan ekspresi diri dan kepekaan terhadap aturanaturan sosial (Keser et al., 2011). Selain itu, pengembangan keterampilan seperti rasa empati dan komunikasi; membangun kesadaran akan perbedaan dan menghargai perbedaan dalam lingkungan sosial mereka, mengembangkan kepekaan terhadap nilai dan norma yang ada menjadi penting dalam pengembangan warga negara yang aktif.

Hasil analisis dan penelitian ini juga menguatkan penelitian Bundick (Bundick, 2011, hal. 57-58), bahwa partisipasi dalam kegiatan ekstrakurikuler di sekolah tinggi dapat mengembangkan hasil yang diinginkan, seperti pencapaian dalam hal mengurangi masalah perilaku. Orang-orang muda merasakan kegiatan ekstrakurikuler yang mereka ikuti menjadi dasar untuk perubahan ke arah yang positif. Hal yang senada juga disampaikan oleh Eccles. dkk (2004, hal. 865), bahwa terdapat hubungan kegiatan ekstrakurikuler dengan pengembangan pemuda ke arah yang positif, kegiatan ekstrakurikuler dengan hasil pendidikan yang baik dan tingkah laku yang baik pula selama masa remaja dan dewasa, kegiatan ekstrakurikuler mencapai hasil dari 
pendidikan yang lebih baik. Partisipasi aktivitas ekstrakurikuler terstruktur telah dikaitkan dengan banyak hasil positif yaitu dalam hal akademik, perilaku, dan psikologis para pemuda dan orang dewasa (Feldman \& Matjasko, 2005).

Berdasar hasil analisis dan beberapa uraian di atas, membuktikan bahwa kegiatan ekstrakurikuler bertujuan untuk membina dan mengembangkan bakat, minat dan serta merupakan upaya untuk pembentukan pribadi yang lebih baik. Pribadi yang lebih baik di sini yaitu membentuk mahasiswa untuk lebih peka terhadap aturan dan norma yang ada, rasa empati dan komunikasi, dan menghargai perbedaan. Hal yang perlu dipertegas adalah kegiatan ekstrakurikuler tidak merebut apa pun dari kurikulum pendidikan akademik. Kegiatan ekstrakurikuler justru memenuhi kebutuhan lainnya dari kegiatan akademik yaitu mampu meningkatkan pengalaman dan partisipasi peserta didik. Selain itu kegiatan ekstrakurikuler dapat memenuhi tuntutan penguasaan kompetensi tentang pelajaran, pembentukan karakter, peningkatan kecakapan hidup, dan mengurangi masalah perilaku.

Berdasarkan hasil analisis regresi sederhana dan berganda, serta berdasar pembahasan hasil analisis di atas terlihat bahwa micro teaching dan kegiatan ekstrakurikuler mahasiswa secara bersamasama berpengaruh signifikan terhadap pembentukan karakter tanggung jawab mahasiswa. Hal ini berarti semakin baik micro teaching dan kegiatan ekstrakurikuler yang dilakukan mahasiswa, maka semakin baik pula pembentukan karakter tanggung jawab mahasiswa Prodi PPKn Universitas Negeri Yogyakarta.

\section{SIMPULAN}

Terdapat pengaruh positif dan signifikan micro teaching terhadap pembentukan karakter tanggung jawab mahasiswa Prodi PPKn Universitas Negeri Yogyakarta. Hal ini dapat dilihat dari nilai signifikansinya 0,000 $(<0,05)$ dan thitung sebesar 5,762 dan t tabel sebesar 2,000 (thitung $>$ tabel). Sumbangan efektif variabel micro teaching sebesar $34,6 \%$. Terdapat pengaruh positif dan signifikan kegiatan ekstrakurikuler mahasiswa terhadap pembentukan karakter tanggung jawab mahasiswa Prodi PKn Universitas Negeri Yogyakarta. Hal ini dapat dilihat dari nilai signifikansinya $0,002(<0,05)$ dan $\mathrm{t}$ hitung sebesar 3,221 dengan $\mathrm{t}$ tabel sebesar 2,000 (thitung $>$ ttabel). Sumbangan efektif kegiatan ekstrakurikuler sebesar $10,4 \%$ terhadap pembentukan karakter tanggung jawab mahasiswa. Terdapat pengaruh positif dan signifikan micro teaching dan kegiatan ekstrakurikuler mahasiswa secara bersama-sama terhadap pembentukan karakter tanggung jawab mahasiswa Prodi PKn Universitas Negeri Yogyakarta. Hal ini dibuktikan dengan nilai $\mathrm{F}$ hitung sebesar 20,823 lebih besar dari F tabel dengan df 2: $51(20,823>3,18)$ dan nilai signifikansi sebesar 0,000 yang berarti kurang 
dari 0,05 $(0,000<0,05)$. Koefisien determinasi $\left(\mathrm{R}^{2}\right)$ sebesar 0,450 atau $45,0 \%$. Hasil ini mengindikasikan bahwa pembentukan karakter tanggung jawab dapat dijelaskan oleh variabel micro teaching dan kegiatan ekstrakurikuler sebesar 45,0\%, sedangkan sisanya sebesar $55,0 \%$ dijelaskan oleh variabel lain yang tidak diteliti.

\section{DAFTAR PUSTAKA}

Asmani, J. M. (2010). Pengenalan dan pelaksanaan lengkap micro teaching dan team teaching. Yogyakarta: Diva Press.

Austad, C. A. (1972). Personality correlates of teacher performance in a micro-teaching laboratory. The Journal of Experimental Education, 40(3), 1-4.

Bundick, M. J. (2011). Extracurricular activities, positive youth development, and the role of meaningfulness of engagement. The Journal of Positive Psychology, 6(1), 57-74.

Cogan, J., \& Derricott, R. (Ed.). (1998). Citizenship for the 21st century: an international perspective on education. London: Kogan Page.

Eccles, J. S., Barber, B. L., Stone, M., \& Hunt, J. (2004). Extracurricural activities and adolescent development. Journal of Social Issues, 59(4), 865-889.

Feldman, A. F., \& Matjasko, J. L. (2005). The role of school-based extracurricular activities in adolescent development: A comprehensive review and future directions. Review of Educational Research, 75(2), 159-210. https://doi.org/10.3102/0034654307500215 9

Hamalik, O. (2007). Dasar-dasar Pengembangan
Kurikulum. Bandung: PT. Remaja

Rosdakarya.

Hamalik, O. (2010). Proses belajar mengajar. Jakarta: Bumi Aksara.

Keser, F., Akar, H., \& Yildrim, A. (2011). The Role of Extracurricular Activities in Cybersecurity Education. Journal Curriculum Studies, 43(6), 809-837. Diambil dari https://www.cerias.purdue.edu/nace/papers/ Dunn.pdf

Lickona, T. (2009). Educating for character: How our schools can teach respect and responsibility. New York: Bantam Books.

Narvaez, D., \& Lapsley, D. K. (2008). Teaching moral character: Two Alternatives for teacher education. The Teacher Educator, 43(2), 156-172. https://doi.org/10.1080/0887873070183898 3

Nuci, L., Narvaez, D., \& Krettenauer, T. (Ed.). (2014). Handbook of moral and character education (2 ed.). New York: Routledge.

Reed, C. L. (1970). The effect of microteaching, directive and non-directive lectures on achievement and attitudesin a basic educational psychology course. The effectof mode of feedback in microteaching. Washington, D.C: American Educational Research Association.

Spears, L. C. (2010). Character and servant leadership: Ten character of effetive, caring leader. The Journal of Virtues \& Leadership, 1(1), 25-30.

Thamrin. (2012). Karakter budaya akademik dan hubungannya dengan prestasi belajar mahasiswa jurusan pendidikan ekonomi FE 
Muhammad Arif Al-Fikri dan Marzuki $\mid$ Pengaruh micro teaching dan kegiatan ekstrakurikuler...

Universitas Negeri Medan. JURNAl

MEDIASI, 4(1), 26-35.

Winarni, S. (2013). Integrasi pendidikan karakter dalam perkuliahan. Jurnal Pendidikan

Karakter, III(1), 95-107.

https://doi.org/10.21831/JPK.V0I1.1291 